\title{
Review on milk and milk product safety, quality assurance and control
}

\author{
Merwan Ahmedsham, Nezif Amza and Metekia Tamiru* \\ Department of Animal Science, College of Agriculture and Veterinary Medicine, Jimma University, P.O. Box 307, \\ Jimma, Ethiopia.
}

Received 28 August, 2017; Accepted 20 October, 2017

\begin{abstract}
Food safety and quality are critical issues that should be given more attention all over the world mainly from nutritional quality and human health point of view. Food safety is a scientific field of study which deals with handling, preparation, and storage of food in ways that prevent food borne illness. Food safety system is often categorized into two, namely traditional and science-based systems. Food can be used as a source of disease transmission from one person to another; it also serves as a nutrient growth medium for bacteria that can cause food poisoning, and hazardous agent for consumers' health. Factors which can be a source of potential hazards in foods include traditional milk production accompanied with improper agricultural practices and poor hygienic environment at all stages of the food chain. Quality assurance is mandatory before the milk is consumed. It is achieved up on planned and systematic activities performed in each steps of the quality system. Milk and milk products contaminants are classified into two, namely, infectious and non-infectious agents. Food-borne illnesses are generally infectious or toxic in nature and caused by major infectious diseases such as bacteria, viruses, parasites, or chemical substances getting access to enter into the body through contaminated food or water. Milk and milk products heading for export to global market need to pass through the strictest quality standards. Hazard analysis and critical control point system (HACCP) requires a critical examination through every step of food manufacturing process to determine the possibility of having physical, chemical, or microbiological contamination. To achieve this, it is necessary to control the quality of milk at the grass root level.
\end{abstract}

Key words: Milk, contamination, food safety, quality control.

\section{INTRODUCTION}

Food safety and quality are a rising concern all over the world particularly when it comes to human health. In this regard, many countries have been running quality control programs for all food ingredients including animal source foods (El-Ziney and Al-Turki, 2007). Food safety is a scientific discipline dealing with handling, preparation, and storage of food in the manner that prevents food borne illness. This requires a number of routine activities

*Corresponding author. E-mail: metekiatam@gmail.com, metekia.tasew@ju.edu.et.

Author(s) agree that this article remain permanently open access under the terms of the Creative Commons Attribution License 4.0 International License 
that should be followed to prevent occurrence of potentially severe health hazards. Quality assurance is all about critically planned and systematic activities implemented within all segment of the quality system, and concealed as needed, to provide satisfactory confidence that a certain food item will fulfill the quality requirements. Hazard is a biological, chemical, or physical agent that is contributing likely to cause a great deal of illness or injury in the absence of its control. Wide range of food borne illness can be controlled by routine activities like keeping personal hygiene, proper processing of the food, heat treatment at higher temperature, adequate cooking before consumption and not subjecting the food to temperature where bacteria can grow (Addis and Sisay, 2015).

Therefore, food control is emphasized to be a mandatory regular activity enforced by national or local authorities to grant consumers' protection and ensure that all foods during production, handling, storage, processing and distribution are safe, wholesome and fit for human consumption. Before a given food item is consumed, it should conform to safety and quality requirements, honestly and accurately labeled as prescribed by law (CFSAN, 2007).

Factors which give rise to potential hazards in foods include improper agricultural practices accompanied with traditional milk production; poor hygienic activities at all stages of the food chain; lack of preventive and controlling measures in food processing and preparation operations; misuse of chemicals; contaminated raw materials, ingredients and water; inadequate or improper storage etc (Battu et al., 2004; Buncic, 2006).

Traditional food safety system is often described as a poor food control system in which there would be likelihood of skipping the unsafe food from being discarded and the food could be channeled through the market to end consumers with no punishment of all stakeholders involved in the system (FAO, 2009).

The HACCP approach which is a science based quality control system has been designed to be implemented in food and dairy sector of any nation in the world to make sure that safe food is produced regardless of the production system (Tamime, 2009). Hence, it is necessary to understand the application and principles of quality assurance system to control and assure the quality and safety of milk and milk products at any production level.

\section{Food safety and its importance}

Safety is defined as the state of being safe from undertaking or causing hurt, injury or loss. Food safety means making ensuring that the food does not pose any harm to the consumer while it is being prepared and/or consumed according to its intended use (FAO, 1997). It is a growing global concern, to be given due attention, not only for its continuing importance to public health, but also because of having negative impact on international trade (Burros, 1997).

Food contamination is generally defined as foods that are spoiled or tainted because they either contain microorganisms, such as bacteria or parasites, or toxic substances that make them unfit for consumption. Therefore, contaminated food would inevitably be hazardous agent for consumers' health. Health hazards to the consumer are often grouped into three subgroups: microbiological, physical and chemical (Walstra et al., 2006). The key issue to consider whether a given milk is of quality and safe is to know the chemical, microbiological and physical standards in milk products (Mansel, 2010). Therefore, food safety is extremely indispensible in protecting individuals from infectious agents like bacteria and parasites that can be transmitted through food consumption.

By conducting safe food handling, the extent of illnesses and fatalities to happen can be prevented. Safe food handling starts at production and continues all the way through the preparation process. If unsafe handling happens at any stage, there would be a potential danger. Food handling safety is critical at the consumer level because many consumers have contaminated food through a lack of awareness. By practicing hygiene before the food is handled and ensuring the cleanness of all utensils and surfaces, food contamination can be prevented. The best way to keep the food safe is to allow the food to be thawed in a refrigerator. Cross contamination is thought to have been a common cause of food contamination. Therefore, by using cleaned utensils and surfaces that have not touched other food items, the risk of cross contamination can be greatly reduced (WHO, 2002).

\section{Food safety system}

Food safety system is broadly categorized into two, namely traditional and science-based food safety systems (FAO, 2003).

\section{Traditional food safety systems}

Traditionally food safety system has been described as unsafe food and enforcement tools have been prescribed for removing unsafe food from commerce and punishing parties responsible for it. This shows that it has been reactive and enforcement oriented rather than preventive to reducing the risk of food borne illness. Most developing countries have already had some sort of food control system in place, usually based on hygiene and adulteration/fraud inspection. While these vary to some extent, they usually incorporate food laws and regulations, food control management, inspection and 
Table 1. Effect of bacteria on quality of milk.

\begin{tabular}{|c|c|}
\hline Bacteria & Effect on milk quality \\
\hline $\begin{array}{l}\text { Genus pseudomonas (Pseudomonas fluorescens, Pseudomonas fragi), Genus Bacillus (Bacillus } \\
\text { polymyxa, Bacillus cereus) }\end{array}$ & Spoilage \\
\hline $\begin{array}{l}\text { Brucella spp, Genus staphylococcus (Staphylococcus aureus), Genus streptococcus (Streptococcus } \\
\text { agalactiae), Genus mycobacterium (Mycobacterium tuberculosis) }\end{array}$ & Pathogenic \\
\hline Genus enterobacter (Enterobacteraceae spp) & Both $s \pm p$ \\
\hline $\begin{array}{l}\text { Genus streptococcus (Streptococcus thermophilus), Genus lactococcus (Lactococcus lactis), } \\
\text { Lactococcus lactis sub speices Lactococcus cremoris, Genus leuconostoc (Leuconostoc lactis) }\end{array}$ & Acid fermentation \\
\hline $\begin{array}{l}\text { Genus lactobacillus (L. lactis, L. bulgaricus, L. acidophilus propionibacterium species } \\
\text { Lactococcus lactis subspp lactococcus lactis diacetylactis }\end{array}$ & $\begin{array}{l}\text { Acid production } \\
\text { Flavor }\end{array}$ \\
\hline
\end{tabular}

NB: $s \pm p=$ spoilage and pathogenic. Source: Bergdoll et al., 2005; CAC, 2007; European Commission (2016).

laboratory services, and sometimes mechanisms for information, monitoring, education and communication of the food supply (FAO, 2009). Traditional food safety system is reactive approach with the main responsibility lying on the government, relies on end product inspection and testing, involves no structured risk analysis and the level of risk reduction is not always satisfactory (FAO, 1995). Due to the above and other reasons traditional food safety system remains inefficient and being unable to investigate and resolve many prevailing problems; and cannot effectively deal with the entire range of complex, persistent and revolving challenges that damage different parts of the food chain (Committee on Animal Nutrition, 2003).

\section{A science risk-based food safety system}

In principle, a science-based approach to food safety has not been totally new in its kind. It is associated with various activities such as good agricultural practices, good hygienic practices, good manufacturing practices and Hazard Analysis and Critical Control Point System (HACCP). Scientific evaluation of chemicals in a given food has remained as a long 'tradition'. The new concept it has adopted is the use of risk analysis as a framework to overview and react to food safety problems in a systematic, structured and scientific ways in order to upgrade the quality of decision-making throughout the food chain (FAO, 2003).

\section{Food-safety hazards specific to milk and milk products}

\section{Biological hazards}

Milk and dairy products can be damaged by a variety of micro-organisms, including many zoonotic bacteria and some viruses for example, retroviruses and cytomegalovirus (Kaufmannet al., 2002) (Table 1).

Generally, the microbiological quality of milk during milking is normally good. But, once the milk is secreted from the udder, it can be contaminated by pathogenic micro-organisms from many sources (Loessner and Golden, 2005). Pathogenic bacteria that can be contaminated at different stages of milk production, handling, processing and storage are Genus pseudomonas (Pseudomonas fluorescens, Pseudomonas fragi, Genus Bacillus (Bacillus polymyxa, Bacillus cereus), Brucella spp, Genus Staphylococcus (Staphylococcus aureus), Genus Streptococcus (Streptococcus agalactiae), Genus Mycobacterium (Mycobacterium tuberculosis). There is also one bacterium, called Genus Enterobacter (Enterobacteraceae spp) categorized as pathogenic and spoilage.

Bacteria like Genus pseudomonas (Pseudomonas fluorescens, Pseudomonas fragi), Genus bacillus (Bacillus polymyxa, bacillus cereus) said to be spoiling bacteria. Those bacteria earlier mentioned could cause severe health complications when the contaminated milk is consumed by human beings. Milk should be kept safe while being milked, processed and stored up on creating clean environment across areas where contamination could occur.

Along with keeping the milk quality and safety, a great deal of milk safety and quality measures should be put in place at any segment of milk production, handling, processing and storage to ensure the milk offered to the consumer is of high quality, safe and wholesome. Even though bacteria cause serious health problems, some bacteria, namely: Streptococcus thermophilus, Lactococcus lactis sub spp cremoris, and Leuconostoclactis cause the fermentation of milk to products like yoghurt which is safe to be consumed. The bacterium Lactococcus lactis subspp diacetylactis helps to provide good flavor to the milk (Table 2). As indicated in Table 2, microorganisms like Brucella abortus, Listeria mycobacterium, Bovis monocytogenes, Coxiella burnetii 
Table 2. Main pathogenic micro-organisms associated with milk and dairy products.

\begin{tabular}{|c|c|c|c|}
\hline Pathogen & Main source of infection & Main means of on-farm control & Main means of control in processing and food handling \\
\hline Brucella abortus & $\begin{array}{l}\text { Contact infection (handling infected animals/ } \\
\text { materials); Also via raw milk }\end{array}$ & $\begin{array}{l}\text { Herd health management (vaccination, serological } \\
\text { screening) }\end{array}$ & Milk pasteurization and hygiene precautions for at-risk workers \\
\hline Listeria monocytogenes & $\begin{array}{l}\text { Mainly via raw milk, soft cheeses and infected } \\
\text { animals/materials }\end{array}$ & Hygienic husbandry and herd health management & $\begin{array}{l}\text { Milk pasteurization: Good manufacturing and prevention of post } \\
\text { processing contamination }\end{array}$ \\
\hline Mycobacterium bovis & Mainly via raw milk & $\begin{array}{l}\text { Hygienic husbandry, herd health management, tuberculin } \\
\text { testing and slaughter of positive reactors }\end{array}$ & Milk pasteurization \\
\hline Coxiella burnetii & Via aerosol, milk and tick bites & Tick control and herd health management & Milk pasteurization: Hygiene precautions for at-risk workers \\
\hline $\begin{array}{l}\text { Staphylococcus aureus, } \\
\text { mycotoxins for example, } \\
\text { aflatoxin }\end{array}$ & Mainly via raw milk & $\begin{array}{l}\text { Milking hygiene, mastitis control, feed hygiene and control, } \\
\text { screening tests on animal feed }\end{array}$ & $\begin{array}{l}\text { Milk pasteurization and hygiene practices, testing of milk and dairy } \\
\text { products for M1 aflatoxin metabolite }\end{array}$ \\
\hline
\end{tabular}

Source: adapted from EFSA (2005).

Table 3. Main chemical hazards found in milk and dairy products with corresponding control measures.

\begin{tabular}{lll}
\hline Chemical hazard & $\begin{array}{l}\text { Main means of on farm control - preventive } \\
\text { controls }\end{array}$ & Main means of control in processing and food handling - secondary controls \\
\hline Antibiotics & $\begin{array}{l}\text { Good animal husbandry and veterinary practices } \\
\text { (GVP) }\end{array}$ & Testing at milk collection point \\
$\begin{array}{l}\text { Pesticides and } \\
\text { Insecticides }\end{array}$ & $\begin{array}{l}\text { Use of authorized products, safe application and } \\
\text { observance of withdrawal times }\end{array}$ & Compliance with regulatory controls and periodic testing at milk collection point \\
Food additives & $\begin{array}{l}\text { Use of registered substances, good } \\
\text { manufacturing practices (GMP) }\end{array}$ & Testing of milk and dairy products \\
\hline
\end{tabular}

Sources: Fischer et al. (2003); FAO (2009); WHO (2009).

and S. Aureus and Mycotoxins for example, aflatoxin have been considered to be the main photogenic microorganisms posing a significant health hazard. It is therefore, mandatory to know the main source of infection for each photogenic microorganism and minimize pre disposing factors which could cause the deterioration of milk and milk products quality. Herd health management like vaccination, serological screening, tuberculin testing, tick control, mastitis control, feed hygiene and control, screening tests on animal feed need to be conducted on regular basis. Moreover, the dairy farmers should undertake appropriate controlling measures (pasteurization and hygiene precautions for at-risk workers) while the milk is being processed and handled before provision to consumer.

\section{Chemical hazards}

Chemical hazards can be described as contaminants of naturally occurring toxins, direct and indirect food additives, pesticide and veterinary drug residues and environmental contaminants (for example, dioxins) (WHO, 2009) (Table 3).

\section{Physical hazards}

A physical hazard can be defined as any physical material not normally found in a food which can 
Table 4. Physical hazards origin and control measures.

\begin{tabular}{llll}
\hline Hazard material & Origin/source & Control measures \\
\hline Glass fragments & Bottle, jars, light fixtures and utensils & Examination of incoming materials \\
$\begin{array}{l}\text { Insects or insect fragments and wood } \\
\text { splinters }\end{array}$ & Fields, plant, pest-control process & $\begin{array}{l}\text { Maintenance procedures designed } \\
\text { to avoid contamination }\end{array}$ \\
Dirt, dust or hair & $\begin{array}{l}\text { Unclean storage, environment and } \\
\text { storm }\end{array}$ & $\begin{array}{l}\text { Training in good } \\
\text { hygienepractices }\end{array}$ \\
\hline
\end{tabular}

Source: WHO (2010).

cause illness or injury to the individuals who consume the product. It includes different types of materials often referred to as foreign materials or objects like dirt particles, hair, leaves, rubber and mettle which can get into the milk at the time of milking (Walstra et al., 2006) (Table 4).

\section{Contaminants of milk and milk products}

Dairy product contaminants are described in terms of the extent of different factors that can make the food unsafe including poor handling, poor storage conditions, naturally occurring toxins found in the food itself, contaminated water, pesticides and drug residues and lack of adequate temperature control. Generally, milk and milk products contaminants are often classified into infectious and non-infectious (Mansel, 2010).

\section{Infectious contaminants of milk and milk products}

Contagion in the milk may occur in most cases when the disease- causing organisms (pathogens) get access to enter through cow feces, thus contaminating the outside of the udder and teats, the farm environment (for example, bedding) and the milking utensils. The extent of contamination that occurs depends upon the hygienic measures taken before, during and after the milking process and storage. Microorganisms found in milk vary considerably and may include bacteria, yeasts, molds and bacteriophages. However, bacteria are the most common and numerous frequently occurring in milk and milk products. Generally, the main source of milk contamination includes: commensal or pathogenic flora of the udder or teat canal, the animal's skin, fecal soiling of the udder, contaminated milking equipment and water used to clean the milking equipment and milk storage containers. Moreover, pathogenic organisms from humans, insects, rodents, birds, and other animals may get access to enter into the milk (FSAUK, 2016).

\section{Milk borne infections}

A variety of microorganisms may enter into milk and its products from unprecedented diverse sources, and cause different human health complications due to food-borne illnesses. Food-borne illnesses are usually pathogenic or toxic in nature and caused by bacteria, viruses, parasites, or chemical substances entering the body through contaminated food or water. Milk and milk products could carry organisms and/or their poisonous metabolites called toxins. Most often organisms shedding from human carriers, the environment, milk-producing or other animals, have been agents of milk borne disease (Table $5)$.

\section{Non-Infectious contaminants of milk and milk products}

In developing countries like Ethiopia, milk production has been very low due to poor genetic and management factors accompanied with small scale farming system carried out in villages and unorganized barns. The likelihoods of milk contamination have been very high. The non- infectious contaminants of milk and milk products may occur through the point of milk production all the way to processing. Some of these contaminants include: chemicals/toxins/ drugs (drugs of abuse), milk additives, environmental (heavy metals) and naturally occurring substances (http://oerafrica.org/system/files/9199/assets/9512/dairyproducts-quality-safety-

odule. pdf?file $=1 \&$ type $=$ node $\& i d=9512$ ).

\section{Quality assurance and control of milk and milk products}

Quality assurance and certification schemes (QAS) is generally explained as any code of conduct, standard or set of requisites, which enables stakeholders of the food supply chain to guarantee compliance with what is declared and to signal this to the end or next user.

Generally, QAS tends to differentiate and guarantee products in relation to their biochemical composition; their origin and the origin of the raw material used to produce them; the production techniques used; residues of pesticides in products; the breeding and living conditions of animals and ethical aspects of production (European Communities, 2006). 
Table 1. Common milk borne infections and their sources.

\begin{tabular}{|c|c|c|}
\hline Sources & Milk borne infections & Way of minimization/ elimination \\
\hline $\begin{array}{l}\text { Milk- producing } \\
\text { animals (infected) }\end{array}$ & $\begin{array}{l}\text { Bovine tuberculosis, brucellosis, anthrax, salmonellosis, listeriosis, } \\
\text { leptospira infection, } Q \text { fever, foot and mouth disease, toxoplasmosis } \\
\text { and hypersensitivity reactions }\end{array}$ & $\begin{array}{l}\text { By improvements in animal husbandry, environmental } \\
\text { cleanliness in dairies and processing plants, pasteurization. }\end{array}$ \\
\hline human carriers & $\begin{array}{l}\text { Septic sore throat and diphtheria, typhoid fever, paratyphoid fever, } \\
\text { infectious hepatitis, polio infection, enteritis, amoebiasis and } \\
\text { giardiasis }\end{array}$ & $\begin{array}{l}\text { improvements in water supplies, public health and hygiene, } \\
\text { and pasteurization }\end{array}$ \\
\hline Environment & Botulism, coli infection, rat bite fever and Balentidiasis & $\begin{array}{l}\text { Hygienic production practices, proper pasteurization, } \\
\text { handling and storage }\end{array}$ \\
\hline
\end{tabular}

Source: CAC (2007).

\section{Milk quality control}

Milk quality refers to a blend of characteristics (chemical, physical, bacteriological and aesthetic) that boost up the acceptability of the milk product. Milk safety and quality assurance has been becoming an area of priority and necessity for consumers, retailers, manufacturers and regulators. Globally, the occurrence of food borne diseases has been increasing and international food trade has been disrupted by frequently ongoing disputes over food safety and quality requirements (Lemma et al., 2008; FAO, 2010). Milk and milk products destined to be exported to global market should pass through the strictest quality standards. To achieve the accepted quality standard, it is mandatory to monitor and control the quality of milk at the grass root level. Milk quality control is the utilization of internationally approved tests to ensure the application of approved practices, standards and regulations concerning the milk and its products (FAO, 2011).Milk quality testes are designed to ensure that milk products conform the accepted standards for chemical composition and purity as well as levels of variety of micro-organisms (Kavitha and Archana, 2015).

\section{Area of quality control}

\section{At the farm}

Quality control and assurance must start at the farm where the milk is produced (Mansel, 2010), by using approved practices of milk production and handling and observation of regulations concerning the use of veterinary drugs on lactating animals and regulations against adulterations of milk, etc. (Battu et al., 2004).

\section{At milk collection centers}

All milk collected from different farmers having their own considerable management activities or milk which is bulked from various collecting centers must be checked for its wholesomeness, bacteriological and chemical quality (Felleke et al., 2010).

\section{At the dairy factory and within the dairy factories}

Once the dairy factory has accepted the milk brought from different farmers and numerous collection centers, it holds the responsibility of ensuring that the milk is handled hygienically and processed to various products.

\section{During marketing of processed products}

The government of any country employs public health authorities abiding by the law to check the quality of food ingredients sold for public consumption and may reject substandard or contaminated foodstuffs from being consumed including possible prosecution of culprits. This is done in order to protect the health of the people and keep the interest of the milk consuming public (Felleke et al., 2010).

\section{Milk quality indicators}

Quality milk contains normal chemical composition, completely free from disease causing bacteria and harmful toxic substances, free from sediment and extraneous substances, have lower level of titratable acidity, has good flavor, sufficient in preserving quality and low in 
Table 6. Physical quality measures of milk.

\begin{tabular}{lccc}
\hline Indicator of milk quality & Quality of cow fresh milk & Quality of ewe fresh milk & Quality of goat fresh milk \\
\hline Density & $1.028-1.034 \mathrm{~g} / \mathrm{cm}^{3}$ & $1.034-1.042 \mathrm{~g} / \mathrm{cm}^{3}$ & $1.024-1.040 \mathrm{~g} / \mathrm{cm}^{3}$ \\
$\mathrm{pH}$ value & $6.5-6.7$ & $6.5-6.8$ & $6.4-6.7$ \\
Freezing point & $<-0.517^{\circ} \mathrm{C}$ & $<-0.56^{\circ} \mathrm{C}$ & $<-0.54^{\circ} \mathrm{C}$ \\
\hline
\end{tabular}

Source: Official Journal No. 102/2000.

Table 7. Defining milk quality by density.

\begin{tabular}{|c|c|c|c|}
\hline Dairy product & Its density $\left(\mathrm{kg} / \mathrm{m}^{3}\right)$ & Dairy product & Its density $\left(\mathrm{kg} / \mathrm{m}^{3}\right)$ \\
\hline Fresh whole milk & 1030 & Light cream $20 \%$ fat & 1009 \\
\hline Skimmed milk & 1035 & Evaporated milk $26 \%$ solids & 1066 \\
\hline Heated standardized milk & 1030 & Evaporated milk $32 \%$ solids & 1085 \\
\hline Sweet condensed milk & 1310 & Heavy cream $40 \%$ fat & 988 \\
\hline Sweet whey & 1025 & Buttermilk & 1029 \\
\hline
\end{tabular}

Source: FAO (2011).

bacterial counts (FAO, 2010). It is also the lacteal secretion, practically free from colostrums, obtained by the complete milking of one or more healthy cows, five days after and fifteen days before parturition (U.S. Department of Health and Human Services, 1995) (Table $6)$.

\section{Quality testing methods}

\section{Density and freshness of products}

The density of milk, among others, is usually used for quality test mainly to check for addition of water to milk or removal of cream. Addition of water to milk minimizes milk density, while removal of cream increases it (O'Connor, 1994) (Table 7).

\section{Organoleptic test}

Testing milk for organoleptic characteristics is often called sensory testing and done using the normal senses of sight, smell and taste in order to know the overall quality. Organoleptic tests are sometimes employed to determine if certain type of food or pharmaceutical products can transfer tastes or odors to the materials and components they are packaged in.

\section{Clot-on-boiling test}

It is one of the oldest test to determine too acidic milk $(\mathrm{pH}<5.8)$ or colostrums, containing mastitis. It is known when the milk is changed to form a curd which means the milk must contain many acids, rennet producing microorganisms and colostrums shed from the cow as soon as the cow gives birth. Such milk cannot stand the heat treatment in milk processing and must be rejected (O'Connor, 1994).

\section{Alcohol test}

It is conducted to check the instability of the proteins occurring when the levels of acid increased and acted upon by the alcohol. Also, elevated levels of albumen (colostrums milk) and salt concentrates (mastitis) result in a positive test by curd formation (O'Connor, 1994).

\section{Titratable acidity test}

Titratable acidity is defined as a measure of freshness and bacterial activity in milk. When the milk is left for a while, the bacteria will proliferate by utilizing lactose to convert it to lactic acid, thereby increasing the acidity and decreasing the $\mathrm{pH}$ value. This acidity is said to be developed or real titratable acidity (O'Connor, 1994; Vishweshwar and Krishnaiah, 2005).

\section{Compositional quality measure of milk}

Milk is a highly nutritious substance which contains macro and micro-nutrients, additionally possessing quite a lot number of active compounds that play significant role in both nutrition and health protection (Boza and Sanz Sampelayo, 1997). The composition of milk varies from one milk to another due to a considerable number of factors including breed, age, feed, disease, stage of lactation and milking techniques (McDonald et al., 1995) (Table 8). 
Table 8. Approximate compositional quality measures of milk.

\begin{tabular}{lcc}
\hline Components & Average content (\%) & Ranges \\
\hline Water & 87.1 & $85.3-88.7$ \\
Lactose & 4.6 & $3.8-5.3$ \\
Fat & 4.0 & $2.5-5.5$ \\
Protein & 3.3 & $2.3-4.4$ \\
Casein & 2.6 & $1.7-3.5$ \\
Mineral substance & 0.7 & $0.57-0.83$ \\
Organic acid & 0.17 & $0.12-0.21$ \\
Miscellaneous & 0.15 & - \\
\hline
\end{tabular}

Source: McDonald et al. (1995).

\section{Overview of milk quality standards and regulation}

In most dairy industrialized countries, milk quality is defined by the level of somatic cells count (SCC) and the microbial load of milk in the pre-pasteurized bulk tank. These are the key components of international regulation put in place for milk quality, udder health and the prevalence of clinical and subclinical mastitis in dairy herds (Fatine et al., 2012). High levels of SCC and microbial load indicate poor milk quality due to the fact that it contains reduced curd firmness and increased fat and casein loss in whey. Moreover, reduction of milk shelf life, poor farm hygiene, antibiotic residues and the presence of pathogenic organisms and toxins increase the microbial load of the milk. Problems of public health associated with consumption of raw milk and traditional dairy products obtained from raw milk are common in the developing countries (Makita et al., 2012). As the industry keeps on growing, much attention needs to be paid on food safety measures to ensure a safe and high-quality product for consumers.

\section{Quality regulation}

Governments, all over the world, have put in place various mechanisms for protecting their citizens from food borne illnesses to ensure the socio-economic development of their country. Milk quality standards have been regulated by the respective Food and Drug Administration in the countries. As a result, the EU and USA legislations have been used as a common measure of milk quality standards. More or less in Ethiopia the application of milk quality standard and regulation is comparable world -wide. Regulation in the area of food quality and safety protection has been one the features of regulatory mechanisms established for problems that are difficult to be identified by consumers using their sense of sight, smell, taste or touch when selecting or consuming foods (CAC , 2007). The responsibility of food regulation in Ethiopia has been shared among Ministry of Health, Ministry of Agriculture and Rural Development,
Ministry of Trade and Industry, and Quality and Standards Authority of Ethiopia. However, there has been poor coordination and cooperation among these government regulatory agencies towards implementing quality regulations laid down by the government. On top of this, the country does not possess an updated comprehensive food law that clearly defines and streamlines the activities of each regulatory body (Abegaz, 2004) (Table 9).

\section{Milk quality grading}

In the United States, Grade A milk (fluid grade milk), top quality milk, refers to milk produced in the farms where sufficiently sanitary conditions have been fulfilled to qualify for fluid (beverage) consumption. Grade B milk is referred to as manufacturing grade milk that does not meet the fluid grade standards and can only be used in cheese, butter and nonfat dry milk. Grade C milk is the last grade milk which violates any of the requirements for grade B milk but is not subjected to adulteration (U.S. Department of Health and Human Services, 2011) (Table 10).

\section{Overview of milk safety and standards in Ethiopia}

In Ethiopia, indigenous dairy products are produced by using traditional materials and methods, thus becoming potential hosts for many microorganisms (Alganesh and Fekadu, 2012; Abebe et al., 2013). Previous studies have emphasized that the hygienic practices during production, processing and handling of milk and milk products in different parts of the country are substandard, which made the quality and safety of milk products questionable (Amistu et al., 2015). Milk and milk products in Ethiopia are channeled to consumers through both formal $(2 \%)$ and informal $(95 \%)$ marketing systems (Netherlands Development Organization, 2008). The hygienic condition of milk and milk products channeled through these systems is poor due to limited knowledge 
Table 9. Milk quality standard in Ethiopia and Europe.

\begin{tabular}{|c|c|c|c|c|}
\hline \multirow{2}{*}{ Milk and product } & \multicolumn{2}{|c|}{ Ethiopian standard } & \multicolumn{2}{|r|}{ EU legislation } \\
\hline & TBC & Requirement & Parameters & Requirements \\
\hline \multirow{3}{*}{ Raw cow milk } & Aerobic mesophilic bacteria & $<1,000,000$ & Plate count (cfu) at $30^{\circ} \mathrm{C}$ & $\leq 100000$ \\
\hline & Coliforms & $<50,000$ & SCC & $\leq 400000$ \\
\hline & SCC & $\leq 400000$ & Antibiotic residues & Does not exceed any maximum permitted value \\
\hline \multirow{3}{*}{ Pasteurized liquid milk } & Total plate count & $<10^{5}$ per ml & Temp. On farm storage & $\begin{array}{l}\text { Cooled to } \leq 8^{\circ} \mathrm{C} \text { in case of daily collection or } \leq 6{ }^{\circ} \mathrm{C} \text { if collection is } \\
\text { not daily }\end{array}$ \\
\hline & Fecal coliforms & Nil per ml & Temp. during transport & $\begin{array}{l}\text { Chill chain must be maintained and on arrival at destination } \\
\leq 10^{\circ} \mathrm{C}\end{array}$ \\
\hline & Non fecal coliforms & $<10$ per ml & Temp. prior to processing & $\begin{array}{l}\text { Quickly cooled to } \leq 6^{\circ} \mathrm{C} \text { and kept at that temperature until } \\
\text { processing }\end{array}$ \\
\hline Ergo & TBC & $<10 \mathrm{cfu} / \mathrm{ml}$ & \multirow{3}{*}{$\begin{array}{l}\text { Plate count at } 30^{\circ} \mathrm{C} \text { before } \\
\text { processing }\end{array}$} & \multirow{3}{*}{$\leq 300000$} \\
\hline Butter & TBC & $4.69 \log \mathrm{cfu} / \mathrm{g}$ & & \\
\hline AYIB & $\mathrm{TBC}$ & $<10 \mathrm{cfu} / \mathrm{g}$ & & \\
\hline
\end{tabular}

Source: Teshome and Ketema (2014); Alganesh (2017) and Data compiled from EC (2004e, 2005c).

Table 10. Milk quality grading system.

\begin{tabular}{|c|c|c|c|}
\hline \multirow{2}{*}{ Parameters } & \multicolumn{2}{|c|}{ Grade A } & \multirow{2}{*}{$\begin{array}{c}\text { Grade B } \\
\text { Raw milk }\end{array}$} \\
\hline & Raw milk & Pasteurized milk & \\
\hline Temperature & Cooled to $45^{\circ} \mathrm{F}$. within $2 \mathrm{hrs}$ of milking & Cooled to $45^{\circ} \mathrm{F}$ or less and maintained thereat & Cooled to $40^{\circ} \mathrm{F}$ within $2 \mathrm{~h}$ of milking \\
\hline Bacterial Limits & $\begin{array}{l}\text { Not to exceed } 100,000 \text { and } 300,000 \text { per ml prior to commingling with other } \\
\text { producer milk and pasteurization respectively. }\end{array}$ & Not exceed 20,000 per ml & $\begin{array}{l}1 \text { million per } \mathrm{ml} \text {; the commingled count } \\
\text { is } 3 \text { million per } \mathrm{ml}\end{array}$ \\
\hline Coliform & Nil per ml & $\begin{array}{l}\text { Not to exceed } 10 \text { per ml; provided that in the case of bulk milk } \\
\text { transport shipments shall not exceed } 100 \text { per ml. }\end{array}$ & $\begin{array}{l}>10 \text { and } 100 \text { per } \mathrm{ml} \text { for individual and } \\
\text { bulk transport respectively }\end{array}$ \\
\hline Somatic Cell Count & Not to exceed $1,000,000$ per ml & Not to exceed 750,000 & When Exceed 1,000,000 per ml \\
\hline $\begin{array}{l}\text { Antibiotics or Other } \\
\text { Inhibitors }\end{array}$ & $\begin{array}{l}\text { No zone equal to or greater than } 16 \mathrm{~mm} \text { with the Bacillus } \\
\text { Stearothermophilus disc assay method }\end{array}$ & $\begin{array}{l}\text { No zone equal to or greater than } 16 \mathrm{~mm} \text { with the Bacillus } \\
\text { Stearothermophilus disc assay method }\end{array}$ & Positive but, not harmful \\
\hline
\end{tabular}

Source: U.S. Department of Health and Human Services (2011).

of dairy product handling accompanied with the inadequacy of dairy infrastructure, such as cooling facilities and unavailability of clean water in the production areas (Table 11).

\section{Principles of HACCP and applications to food safety assurance}

HACCP is a scientific and systemic system, which identifies a specific hazard throughout the food chain, that is, from primary production of milk until it reaches the consumer. With increasing demand for dairy products worldwide, it is necessary for 
Table 11 Challenges, constraints and recommendations concerning Ethiopian dairy policy issues.

\begin{tabular}{|c|c|c|c|}
\hline Policy issues & Challenges & Constraints & Policy recommendation \\
\hline $\begin{array}{l}\text { Disease prevalence } \\
\text { and control }\end{array}$ & $\begin{array}{l}\text { Lack of inspection and quality control services to } \\
\text { safeguard the public from zoonotic diseases }\end{array}$ & $\begin{array}{l}\text { Lack of proper livestock movement control, quarantine } \\
\text { and surveillance systems }\end{array}$ & $\begin{array}{l}\text { Design and implementation of appropriate control and prevention } \\
\text { strategies for milk born diseases, such as TB and mastitis }\end{array}$ \\
\hline $\begin{array}{l}\text { Standards and } \\
\text { quality control }\end{array}$ & $\begin{array}{l}\text { Safety and quality standard of dairy products supply } \\
\text { to the consumer not guaranteed }\end{array}$ & $\begin{array}{l}\text { Lack of enforcement of quality control regulations and } \\
\text { standards }\end{array}$ & $\begin{array}{l}\text { Mandatory certification and inspection service, implementation of } \\
\text { standards, legislations on milk quality and assurance }\end{array}$ \\
\hline Dairy information & $\begin{array}{l}\text { Unavailability of information at production, marketing } \\
\text { and consumption level }\end{array}$ & $\begin{array}{l}\text { No organized body in charge of collecting, summarizing, } \\
\text { archiving, analyzing and disseminating }\end{array}$ & Organizing or establishing an institution for dairy information system. \\
\hline Milk processing & Operating under capacity & $\begin{array}{l}\text { Low level and uneven supply of liquid milk with the } \\
\text { required quantity and quality and Promoting demand }\end{array}$ & Facilitation of collection, chilling and transportation facilities \\
\hline
\end{tabular}

Source: FAO (2011).

every dairy industry to adopt HACCP in order to give quality assurance to consumers (DPC, 2001).

A hazard is any aspect of the production chain that is unacceptable because it is a potential cause of harm activated by biological, chemical or physical agent in food with the potential to cause an adverse health effect in humans and animals (CFSAN, 2007). In a country where consumption of raw milk and milk products is common, provision of milk and milk products with superior hygienic quality is required to safeguard the consumers (Zelalem, 2003). HACCP requires a critical examination of the whole food manufacturing process to determine every step where there is a likelihood of physical, chemical, or microbiological contamination. This would make the food unsafe or unacceptable for human consumption. It identifies and sets critical control points (CCP) (DPC, 2001).

Control points are the steps where food production starts at raw stage and passes through processing and shipping to consumption by consumer. Critical control points are the ones in food production system where loss of control can lead to health hazards. Traditionally these practices were used to reduce manufacturing defects in dairy products and ensure compliance with specifications and regulations. However, they have many drawbacks e.g. they are destructive and time-consuming, they have slow response, allow small sample size to work with and they delay in the release of food principles to HACCP. There are over seven principles to HACCP: Analyze hazards, Determine critical control points, Establish critical limits, Establish monitoring procedures, Establish deviation procedures, Establish verification procedures and Establish record keeping procedures (CFSAN, 2007; CAC 2007).

\section{Economic benefits of food safety system and quality assurance}

Food safety plays a significant role in the national economy and health by; safe- guarding the health of the nation through improved nutrition, enhancing national and international trade, preventing avoidable losses at pre/post-harvest, reducing public health costs by decreasing food borne illness and reducing export and trade barriers, resulting in countries becoming competitive in the global trade (WHO, 2005).

\section{CONCLUSION AND RECOMMENDATION}

Milk is a safe and nutritious food that should be harvested, processed and handled properly.
Identifying source of contaminants in food production and processing, as well as implementing good production practice, is very important for ensuring consumers' health. As milk leaves the cow, it is dominated by lactic acid bacteria. However, during storage pathogenic bacteria introduced from the environment can cause spoilage of raw milk.

A mild heat treatment such as thermization can destroy most of the spoilage bacteria. Prolonged exposure of dairy product to heat can destroy the nutrients in milk such as vitamins and protein. Thus, knowledge of the microbiological flora of raw milk before and after different heat treatments is essential for ensuring the safety and quality of milk at consumption. Quality control measures have been advanced to provide better tools for the evaluation of different quality parameters of milk at different stages of the production. The availability of standardized methods, as well as harmonized guidelines developed by specialized international agencies, has been essential to establish method of performance.

In order to ensure a proper quality of milk and its derived products, HACCP was proposed and applied in many countries as a systematic preventive approach and an efficient path to design measurements to reduce risks to a safe level. High quality of milk is necessary for 
consumption and eligible for export thereby contributing to the national economy through foreign currency. Therefore, dairy enterprises and small scale farmers should produce quality milk at each production stage so that they will be profitable with attractive price of their products and will be appreciated by the government for their significant contribution towards minimizing the risk of food borne illnesses emanating from contaminated milk and milk products.

\section{CONFLICT OF INTERESTS}

The authors have not declared any conflict of interests.

\section{REFERENCES}

Abebe B, Zelalem Y, Ajebu N (2013). Handling, processing and utilization of milk and milk products in Ezha district of the Gurage zone, Southern Ethiopia. J. Agric. Biotech. Sustain. Dev. 5(6):91-98.

Addis M, Sisay D (2015). A Review on Major Food Borne Bacterial Illnesses. J. Trop. Dis. 3:176.

Alganesh TG, Fekadu B (2012).Traditional milk and milk products handling practices and raw milk quality in Eastern Wollega, Ethiopia. In: Laura Dean (ed.) LAP Lambert Academic Publishing. HeinrichBöcking-Str. 6-8, 66121 Saarbrücken, Germany www.lappublishing.com pp .85. ISBN 978-3-8484-3573-9. 4.

Alganesh TG (2017). Status and Challenges in the Safety and Quality of Dairy Products in Ethiopia: A Review. J. Food Sci. Qual. Manag. ISSN 2224-6088 (Paper) ISSN 2225-0557 (Online) Vol.59.

Amistu K, Degefa T, Melese A (2015). Assessment of raw milk microbial quality at different critical points of Oromia to Milk Retail Centers in Addis Ababa. Food Sci. Qual. Manag. 2015(38):1-9.

Battu R, Singh SB, Kang BK (2004). Contamination of liquid milk and butter with pesticide residues in the Ludhiana district of Punjab state, India. Ecotoxicol. Environ. Saf. 59:324-331.

Bergdoll MS, Lee WAC (2006). Staphylococcal intoxications. Foodborne Infect Intox. 3:523-552.

Boza J, Sanz Sampelayo MR (1997). Aspectos nutricionales de la leche de cabra. Anales de la Real Acad. Cien. Vet. Andalucía Oriental.10:109-139.

Buncic S (2006). On-farm phase in the context of the food chain Integrated Food Safety and Veterinary Public Health (ed. S. Buncic), CABI, Oxford. pp. 26-31.

Burros M (1997). Clinton to battle food borne illness. New York Times. January 24, 1997.

Codex Alimentarius Commission (CAC) (2007). Codex Alimentarius Commission - 17th Procedural Manual, Rome: Codex Alimentarius Commission (CAC (2007).

CFSAN (Center for Food Safety And Applied Nutrition) (2007). Hazards \& Controls Guide For Dairy Foods. HACCP Guidance for Processors Version 1.1 June 16, 2006. Center for Food Safety And Applied Nutrition, USA.

Dabhol Power Company (DPC) (2001). Hazard Analysis Critical Control Point system - HACCP for

the dairy industry. Guideline No. 55 in Guidelines for the Dairy Industry Relating to Sanitation and Milk Quality, Volume 4 . Ed. Dairy Practices Council. Keyport.

EFSA (European Food Safety Authority) (2005). Statement of the Scientific Panel on Contaminants in the Food Chain to a summary report on Acrylamide in food of the 64th meeting of the joint FAO/WHO Expert Committee on food additives. The EFSA J. 619:1-

El-Ziney MG, Al-Turki Al (2007). Microbiological quality and safety assessment of camel milk (Camelus dromedaries) in Saudi Arabia. Appl. Ecol. Environ. Res. 5(2):115-122. Penkala Bt., Budapest, Hungary.
European Commission (2005c). Final report of a mission carried out in estonia from 05 to 09 september 2005 concerning animal welfare controls, dg (sanco)/7714/2005 - mr final.

European Communities (2006). Food quality assurance and certification schemes. Background Paper. Stakeholder Hearing .11/12 May 2006.

Food and Agriculture Organization (1995). Strategies for market orientation of small scale milk producers and their organizations, Proceedings of a Workshop, eds. L.R. Kurwijila, J. Henriksen, A.O.O Aboud and G.C. Kifaro/Sokoine University of Agriculture, FAO Rome.

Food and Agriculture Organization (1997). Gender: the key to sustainability and food security[online]. SD Dimensions, May 1997. Rome, Sustainable Development Department.

Food and Agriculture Organization (2003). Workshop on the prospective on the application of lactoperixidase system in milk handling and preservation in Indonesia.FAO. Jakarta.

Food and Agriculture Organization (2005). Nutrition indicators for development, by B. Maire \& F. Delpeuch. Rome.

Food and Agriculture Organization (2009). The State of Food and Agriculture. Rome, Italy.

Food and Agriculture Organization (2010). Status and Prospects for Small Holder milk production. A global perspective. Rome, Italy.

Food and Agriculture Organization (2011). A Review of the Ethiopian Dairy Sector. FAO Sub Regional Office for Eastern Africa (FAO/SFE).

Fatine H, Abdelmoula E, Doha B, Hinde H (2012). Bacterial quality of informally marketed raw milk in Kenitra City, Morocco. Pak. J. Nutr. 11(8):662-669.

Felleke G, Woldearegay M, Haile G(2010). Inventory of Dairy Policy of Ethiopia, Target Business Consultants Plc, Netherlands Development Organization (SNV), Addis Ababa, Ethiopia.

Fischer WJ, Tritscher AM, Schilter B, Stadler RH (2003). Contaminants resulting from agricultural and dairy practices. In: Roginski $\mathrm{H}$.: Encyclopedia of Dairy Sciences. Vol. 1. Elsevier Science, London: pp 516-525

Food Standards Agency of United Kingdom - FSAUK (2016). Review on a Practical Guide for Milk Producers.

http://oerafrica.org/system/files/9199/assets/9512/dairy-productsquality-safety module.pdf?file=1\&type=node\&id=9512.

Jay JM, Loessner MJ, Golden DA (2005). Modern Food Microbiology. 7th Edition, Springer Science and Business Media, Inc., New York, pp 63-90, 101-125.

Kaufmann S, Sher A, Ahmed R (2002). Immunology of Infectious Diseases, American Society for Microbiology, Washington, D. C. pp. 1-495.

Kavitha V, Archana P (2015). Quality Assessment of Different Milk Brands Available in Kottayam District, Kerala. Int. J. Adv. Nutr. Health Sci. 3(1):137-142.

Lemma T, Tegegne A, Puskur R, Ranjitha P, Hoekstra D (2008). Moving Ethiopian smallholder dairy along a sustainable commercialization path: missing links in the innovation systems: Improving Productivity and Market Success (IPMS) Project, ILRI, Addis Ababa, Ethiopia.

Makita K, Desissa F, Teklu A, Zewde G, Grace D (2012). Risk assessment of staphylococcal poisoning due to consumption of informally-marketed milk and home-made yoghurt in Debre Zeit. Ethiopia. Int. J. Food Microbiol. 153(1-2):135-141.

Mansel WG (2010). Improving the safety and quality of milk. Wood head publishing series in food science, technology and nutrition. Milk production and processing. Volume. 1.

McDonald P, Edwards RA, Greenhalgh JFD (1995). Animal Nutrition 5th. Longman;London, UK.

Netherlands Development Organization (2008). Investment opportunity in dairy sub-sector of Rwanda. 1st Draft. Kigali, Rwanda.O'Connor CB (1994). Rural Dairy Technology ILRI Training Manual 1. ILRI (International Livestock Research Institute), Addis Ababa, Ethiopia. $133 \mathrm{p}$.

Tamime AY (2009). Milk Processing and Quality Management.Society of dairy technology. Blackwell Publishing Ltd. ISBN: 978-1-405 14530-5.

Teshome T, Ketema B (2014). Microbiological Quality and Safety of Raw Milk Collected from Kersa District, Jimma Zone, Southwest Ethiopia. J. Biol. Chem. Res. 31 (1):546-561.

U.S. Department of Health and Human Services (1995). Public Health 
Service, Centers for Disease Control and Prevention (CDC). Hyattsville, Maryland.

U.S. Department of Health and Human Services (2011). Grade "A" Pasteurized Milk Ordinance. Public Health Service, Food and Drug Administration.

Vishweshwar SK, Krishnaiah N (2005).Quality Control of Milk and Processing (for the course of dairying). State institute of vocational education director ofintermediate education govt. of Andhra pradeshsindo or graphics, India.

Walstra P, Wouters JM, Geurts TJ (2006). Dairy Science and Technology.Second Edition.CRC Press Taylor \& Francis Group. P. 763.

World Health Organization (WHO) (2002). Global Strategy for Food Safety: Safer Food for Better Health (Food Safety Issues), World Health Organization, Geneva.
World Health Organization (WHO) (2005). Guiding Principles for Feeding non-breastfed Children 6-24 months of age. 20 Avenue Appia 1211 Geneva 27, Switzerland.

World Health Organization (WHO) (2009). Milk fluoridation for the preservation of dental cariers. WHO. Geneva.

World Health Organization (WHO) (2010). Retrieved 2010-1210."Prevention of foodborne disease: Five keys to safer food". xxx Pravilnik o kakvoi svježeg sirovog mlijeka. Official Journal No.102 / 2 000 . Of 17. 10. 2000. 